\title{
A Forgotten Press Building at Lamluda
}

\author{
Ahmed Mustapha Buzaian ${ }^{1}$
}

\begin{abstract}
Presented here are the preliminary results of the unfinished excavations conducted by Richard Goodchild in the late 1950s at Lamluda, east of Cyrene on the upper plateau of the Jebel Akhdar. One of the most interesting discoveries was a wellpreserved press complex comprising a press and series of associated rooms, including a storage magazine. The evidence indicates that the complex was probably used for producing wine rather than olive oil; it appears to be of Late Roman or more likely of sixth-century date. This date is indicated by a reused stone bearing three faint carved Maltese crosses found incorporated within Room A. It is clear that parts of the complex were later modified; it is tempting to relate this later activity to continued occupation of the site after the Arab conquest.
\end{abstract}

\section{Introduction}

The site of Lamluda is located on the upper plateau of the Jebel Akhdar $30 \mathrm{~km}$ east of Cyrene, south of the main east-west road crossing Cyrenaica (at $32^{\circ} 46.812^{\prime} \mathrm{N}, 22^{\circ} 09.300^{\prime} \mathrm{E}$ ). The settlement lies adjacent to a T-junction with a road heading north to the coast at Ras al-Hilal, a location well known from the survival of several impressive Hellenistic tombs located on either side of the road. Pacho and others tentatively identified the settlement with ancient Limnias (Roques 1987, 125, 401, 405; Ward-Perkins and Goodchild 2003, 294-302).

Ward-Perkins and Staples visited the site in 1955 and initiated a survey concentrating mainly on the remains of two churches. In the late 1950s Richard Goodchild conducted a limited excavation on the western fringe of the settlement and found a north/south-running street flanked by buildings associated with oil and wine production (Ward-Perkins and Goodchild 2003, 294-302) (Figs 1 and 2). At least four uprights of presses (arbores) were found in situ in buildings on either side of the street, clearly suggesting that the buildings were contemporary with the production of wine or olive oil. One of the most interesting discoveries was a well-preserved press complex comprising a press room (Goodchild 1968) and a series of associated rooms including a storage magazine, located midway along the west side of the street. Sadly, Goodchild's excavation was never published and the site has been forgotten for over 50 years, buried beneath a carpet of vegetation.

In 2008, the Italian mission of Chieti University cleared Goodchild's excavation of bushes as part of a project to plan the site and to assess the development of Lamluda (Menozzi and Fossataro 2008, 135-136). With the kind consent of the mission, the writer was allowed to conduct a survey of uprights, crushing basins, counterweights and crushing stones across the site and to map their location. ${ }^{1}$ As part of this survey a more detailed study of the press complex was made and this work forms the subject of this article.

\section{The press building}

The press complex comprised a rectangular block of at least six rooms measuring $25 \mathrm{~m}$ by $12 \mathrm{~m}$ aligned with its long axis parallel to the street (Fig. 3). Three rooms occupied the southern third of the block. The west room (A) contained two presses and occupied a full half of the space available. The remaining two rooms (D1 and D2) were of roughly equal size and adjoined the street. To the north and connected by a doorway were at least two rectangular rooms, possibly extending for the full length of the building. They may have had three vaulted bays aligned with the long axis parallel to the street. The west room (C) was of single bay width. The north end of the room was not clear of vegetation at the time of the survey but it is thought likely that the single bay continued to the north wall of the complex. The room to the east (B) was of two bays, almost certainly vaulted and originally contained at least ten sunken dolia. 


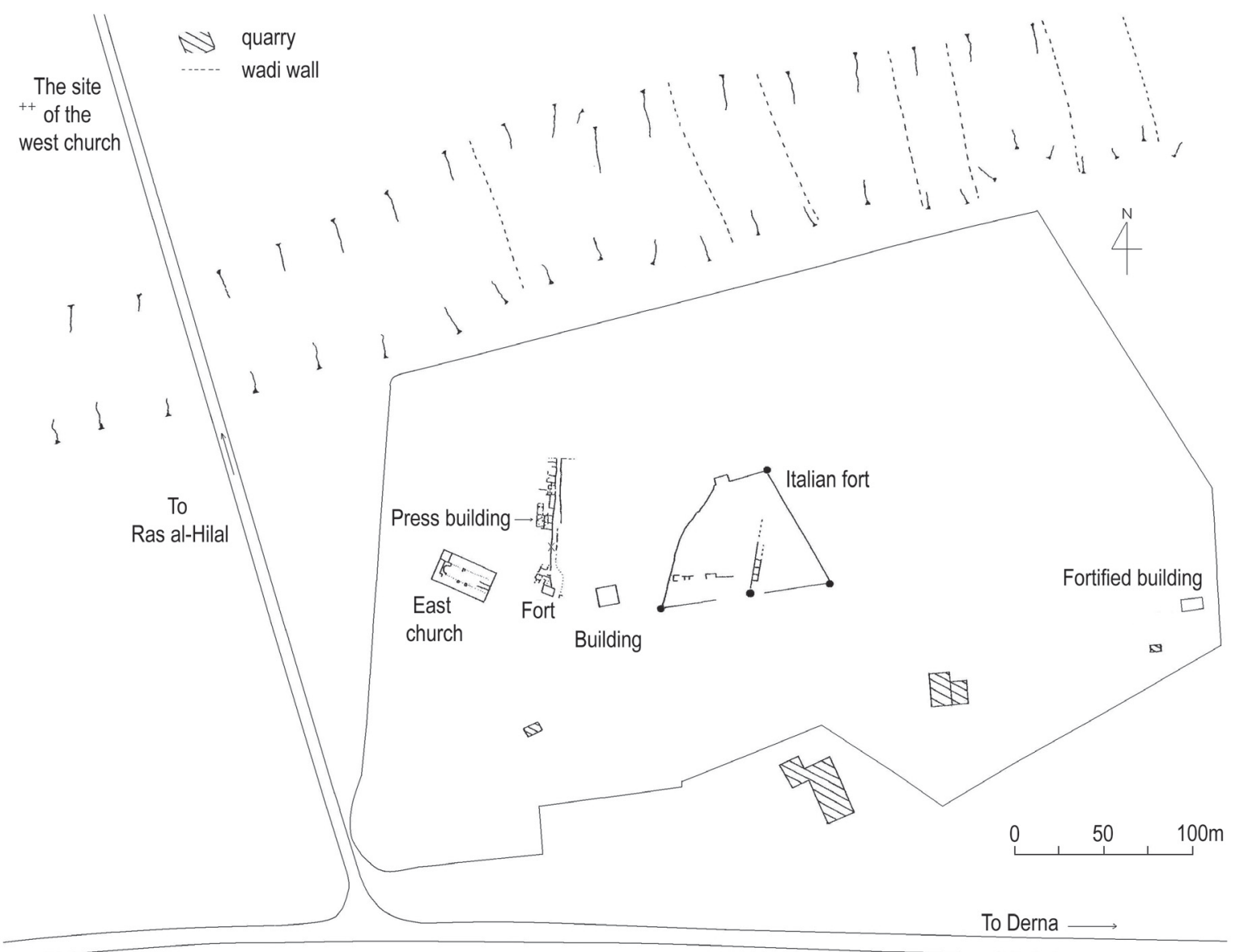

Figure 1. Plan of Lamluda showing the location of the press building.

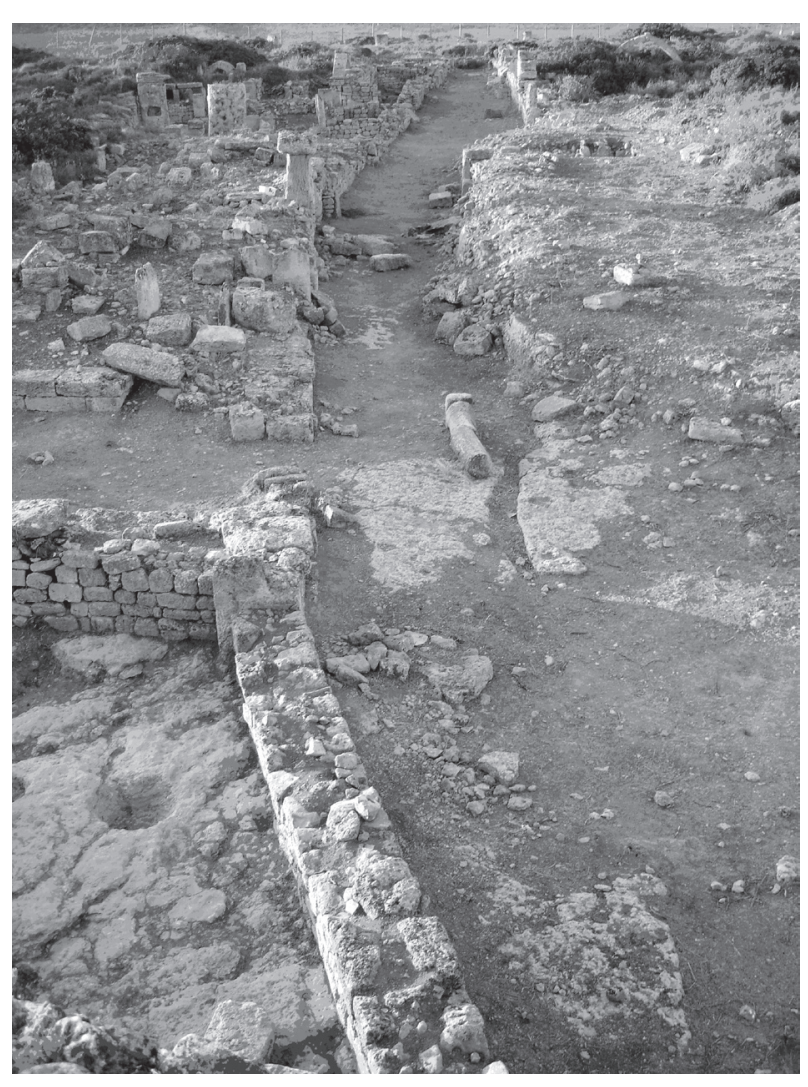

Figure 2. General view of the street and press complex, looking north.

\section{Room A}

Room A, measuring $5.4 \mathrm{~m}$ east/west by $9.75 \mathrm{~m}$ north/south, housed at least two presses with a possible third press located in the unexcavated corner of the room (Fig. 4). The walls of the room, in places surviving to a height of over $1 \mathrm{~m}$ above the contemporary bedrock floor, were faced with roughly squared stones on average $30 \mathrm{~cm}$ by $20 \mathrm{~cm}$ by $15 \mathrm{~cm}$ in size. Between the faces was a rubble fill of small stones bonded in mud mortar.

There were many features in the room suggesting that it was used for manufacturing purposes. A single monolithic stone (1) $1.9 \mathrm{~m}$ high, $1.2 \mathrm{~m}$ wide and $80 \mathrm{~cm}$ thick, an upright for a press, was incorporated in the north-west corner of the room (Fig. 5). A second block measuring $1.40 \mathrm{~m}$ by $60 \mathrm{~cm}$ by $40 \mathrm{~cm}$ capped the upright, probably to add stability. A small sub-rectangular niche cut in the exposed face of the upright measured $60 \mathrm{~cm}$ by $40 \mathrm{~cm}$ and $40 \mathrm{~cm}$ deep, was designed to house the end of a press beam (Goodchild 1968, 24). In front of the 

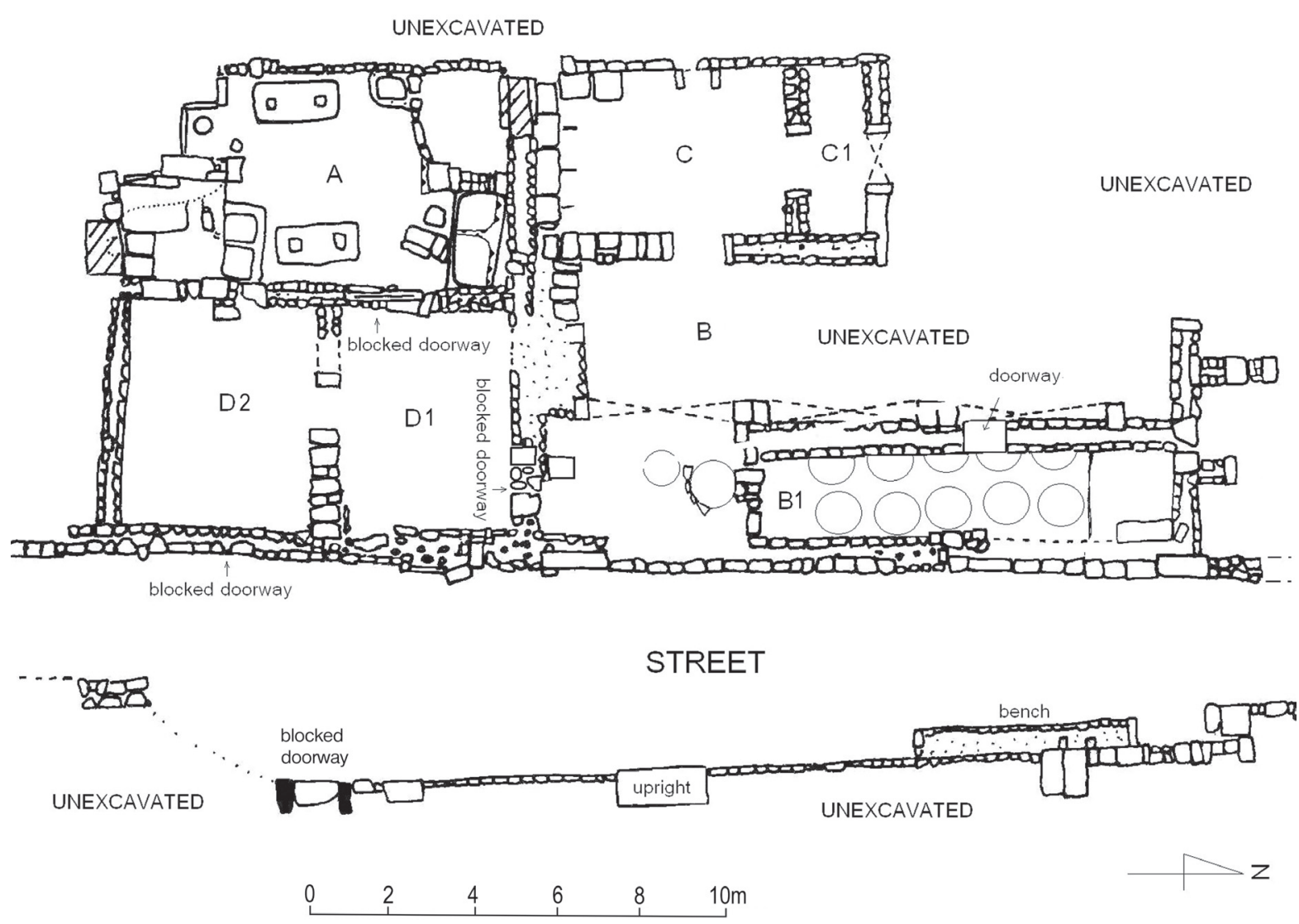

Figure 3. General plan of the complex.

upright was a tank (2). The lower edge of the niche (the underside of the beam) was located $50 \mathrm{~cm}$ above the floor of the tank. Raised above the floor, $60 \mathrm{~cm}$ deep and lined with waterproof mortar, the tank was irregular in shape, measuring $2 \mathrm{~m}$ by $2.3 \mathrm{~m}$.

The east wall of the tank, of small blocks laid at $90^{\circ}$ to the north wall, separated the structure from a second tank (3). The south wall of tank 2 incorporated a small regular block with faint traces of three carved Maltese crosses (Fig. 6). The tank was provided with two outlets located in the southwest and south-east corners. That to the south-west conveyed liquid into a small tank (5), $70 \mathrm{~cm}$ deep, measuring $50 \mathrm{~cm}$ by $75 \mathrm{~cm}$. The south-east outlet fed a second vat (4) to the east. The base of the tank (5) may additionally have been provided with a sediment trap but this was not proven, as the tank was not fully excavated. The second tank (3) was rectangular, $2.1 \mathrm{~m}$ by $1.15 \mathrm{~m}$ and $1 \mathrm{~m}$ deep. A similar waterproof lining of mortar $5 \mathrm{~cm}$ thick was applied to this tank and extended to its full height, especially at the corners. The mortar lining at the base of the tank incorporated a T-shaped channel up to $10 \mathrm{~cm}$ wide which drained liquid to the south-east corner of the tank, to empty into vat 4 .

The south wall of the tank was formed of one large slab laid on edge $(1.6 \mathrm{~m}$ by $85 \mathrm{~cm}$ by $15 \mathrm{~cm})$. The channel drained beneath the wall to empty into the vat. The vat was sunk into the ground to a depth in excess of $2.3 \mathrm{~m}$ with a rebated mouth $50 \mathrm{~cm}$ in diameter which would have been closed with a lid. Channels from both tanks fed the bottle-shaped vat, which was at least $1.60 \mathrm{~m}$ in diameter. The channel from tank 2, $13 \mathrm{~cm}$ wide and $15 \mathrm{~cm}$ deep was cut into bedrock and lined with waterproof mortar. Open immediately outside the tank, the channel was then fed underground to drain into the vat.

A large rectangular block (6), located $1.7 \mathrm{~m}$ south of tank 2 was interpreted as a counterweight. The stone measuring $2 \mathrm{~m}$ by $95 \mathrm{~cm}$ by $40 \mathrm{~cm}$ was provided with two identical sockets measuring $25 \mathrm{~cm}$ by $29 \mathrm{~cm}$, set $95 \mathrm{~cm}$ apart. The distance between the counterweight and the upright suggested 


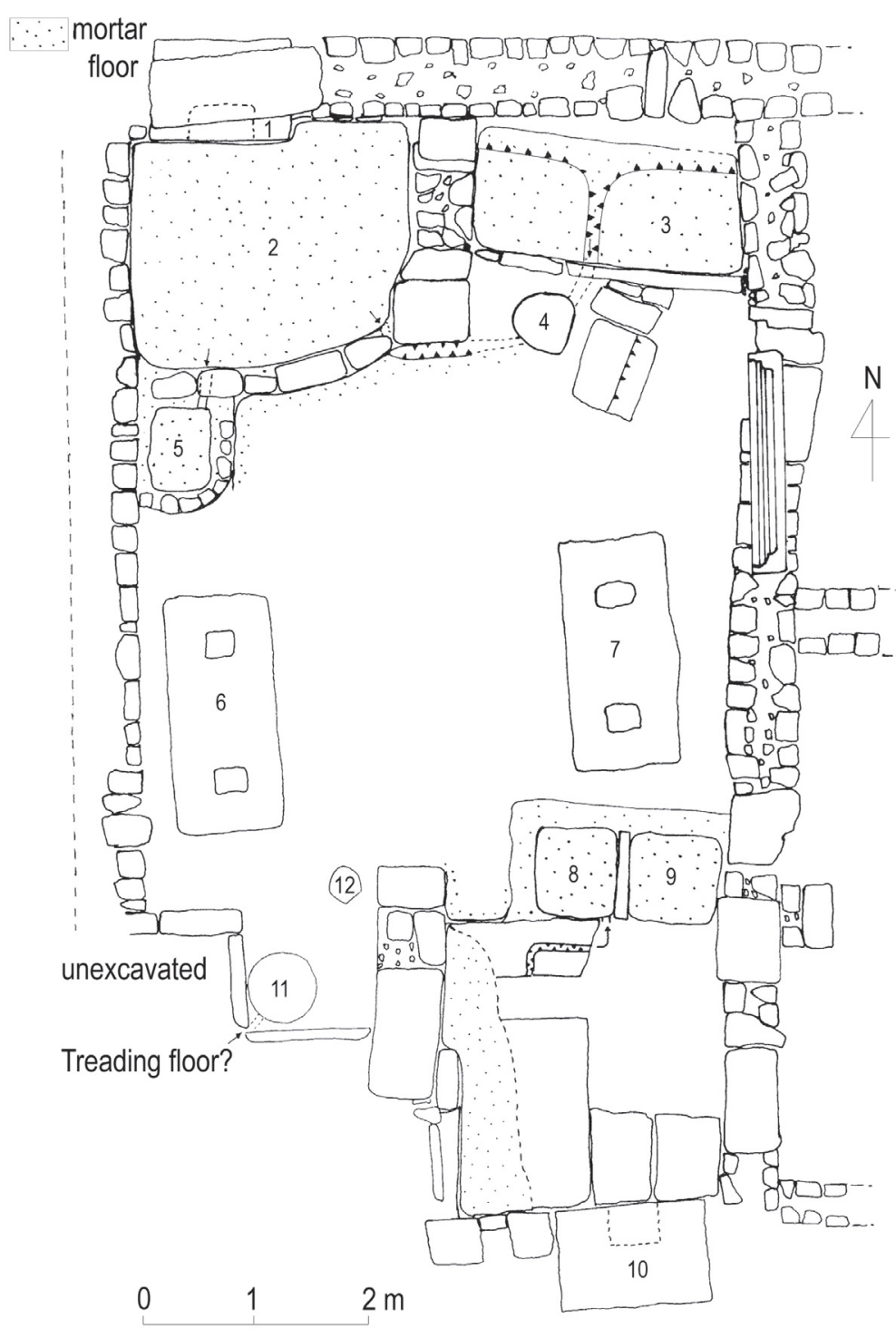

Figure 4. Plan of Room A. a beam length of $6.4 \mathrm{~m}$. A second counterweight block (7) was located in an identical position opposite upright 10 (Fig. 7). This block measuring $2.05 \mathrm{~m}$ by $95 \mathrm{~cm}$ by $40 \mathrm{~cm}$ was provided with two sockets of identical size to those in block 6 but set $85 \mathrm{~cm}$ apart. Block 7 was placed $2.25 \mathrm{~m}$ away from tank 3. The distance between block 7 and upright 10 implied a beam length of $6.3 \mathrm{~m}$. The beam lengths are of similar size to the el-Amud press, recorded as c. $5.5 \mathrm{~m}$ (Barker and Jones 1984; Mattingly and Dore 1996, figs 5.27 and 5.28) and a press at Siret Gasrin el-Giamel, estimated as $7.5 \mathrm{~m}$. The slight differences in length are not significant and may be considered an acceptable variation in the regional type of press.

This type of counterweight is regionally specific to Cyrenaica and differs from examples elsewhere in the Roman world. It was placed with its long axis parallel to and just beside the press beam, with two sockets to receive a pair of timber uprights forming part of a windlass to which the free end of the beam was connected by ropes. Two narrow and shallow grooves in the lower edge of the short side of the counterweight block (sometimes the grooves are cut in the long side, usually extending for the full length of the block) cross the socket holes but do not extend for the full width of the block. A peg was inserted in this position to pass through a mortise cut in the lower part of the timber upright, to secure the windlass to the underside of the beam. ${ }^{2}$

Two identical mortar-lined rock-cut tanks ( 8 and 9 ) were located to the south of counterweight 7. Both were $80 \mathrm{~cm}$ by $80 \mathrm{~cm}$ and $70 \mathrm{~cm}$ deep. Tank 8 , to the west, was connected to a $10 \mathrm{~cm}$-wide channel at its south-east corner. Part of the channel had been lost to erosion and was difficult to trace but it seems likely that that it formed part of a channel cut in a stone slab laid directly south of the tank which led from a treading floor located a short way to the south. Although there is no physical connection between the two tanks, liquid is likely to have been directed first into tank 8 (perhaps the tank was provided with a sediment-trap) and then transferred to the adjacent tank. A single stone upright (10), $2.6 \mathrm{~m}$ high, $1.2 \mathrm{~m}$ wide and $90 \mathrm{~cm}$ thick, stood south of the tanks. The upright had an oval niche cut into its front side. The niche, $55 \mathrm{~cm}$ by $45 \mathrm{~cm}$ and $35 \mathrm{~cm}$ deep was positioned $60 \mathrm{~cm}$ above the pressing floor, which was originally surfaced with mortar. A recess built of large stone slabs was inserted in the south-west corner of the pressing room and contained a deep mortar-lined circular vat (11) cut into the bedrock. The vat, over $2.2 \mathrm{~m}$ deep was similar in design to vat 4, but with a circular opening $60 \mathrm{~cm}$ wide and an internal diameter of $1.8 \mathrm{~m}$. A $10 \mathrm{~cm}$-wide channel fed into the vat from the south-west suggesting that a third possible pressing floor existed in the unexcavated 


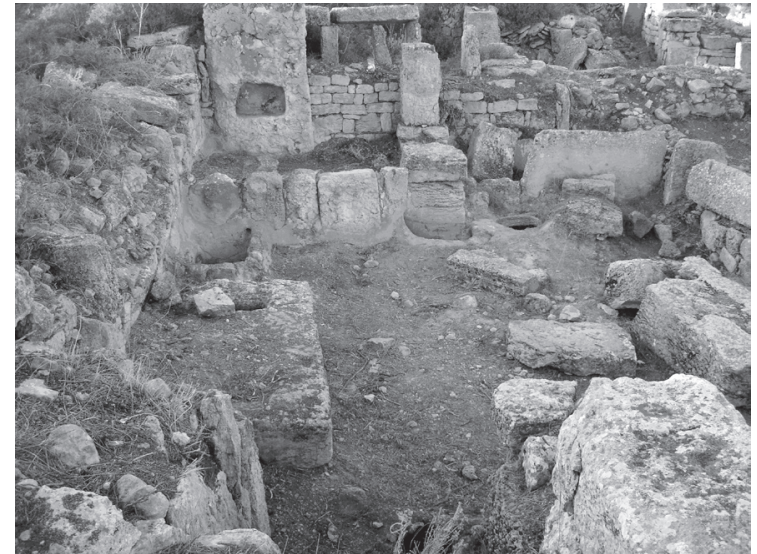

Figure 5. Room A, looking north.

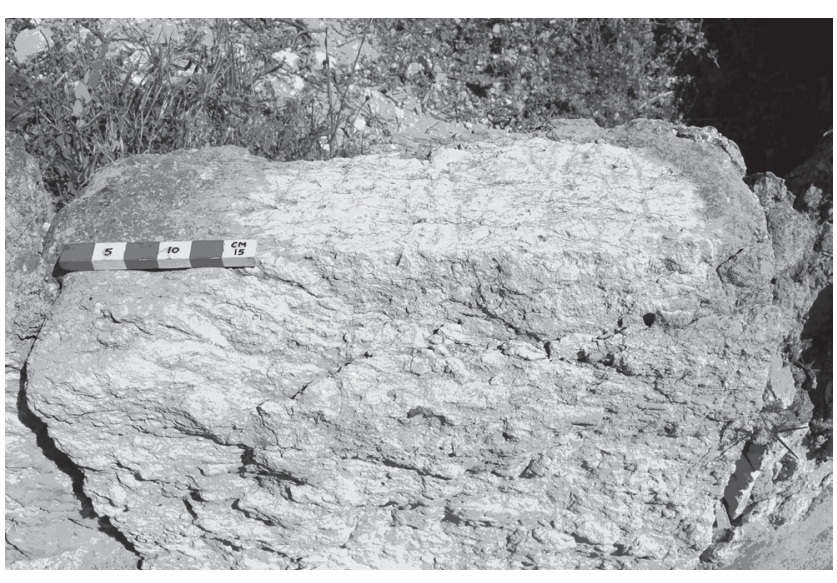

Figure 6. Tank 2. Three faintly visible Maltese crosses carved on a reused block.

area to the south-west. However, as no standing upright existed here, it is possible that vat 11 was connected to a platform or a tank similar to tank 3 and vat 4 on the opposite side of the room. A $30 \mathrm{~cm}$ diameter sub-circular unlined pit (12), $30 \mathrm{~cm}$ deep, was located to the north-east of the vat. The function of the pit is uncertain, but it may have been used to stand an amphora in during the decanting of liquid. Access to Room A was gained through a doorway leading from Room D1. A fallen moulded lintel block may have originally covered the opening.

Two rooms lay to the east of Room A (D1 and D2). The main door of the complex giving onto the street appears to have been located in the east wall of Room D2. Blocked during a later phase of activity, the doorway was $1 \mathrm{~m}$ wide. The room measured $5.9 \mathrm{~m}$ east/west by $4.5 \mathrm{~m}$ north/south. There was no access between Room D2 and Room A, but a doorway in the north wall of Room D2 led into Room D1. Room D2 was possibly the main entrance or perhaps a shop associated with the complex.

Room D1was roughly the same size as D2, but the east wall of Room D1 was exceptionally thick, possibly the result of rebuilding. A doorway set in the centre of the west wall of the room gave access to the press room and a door in the north wall, later blocked, led into Room B. Room D1 was perhaps a vestibule that linked shop, press room and store.

To the north of Room D1 was Room B. In the arrangement contemporary with the press room, this part of the complex was vaulted (the arch of the central vault still survives) and divided into three bays. The south bay of the east vault connected with the vestibule and contained two unrelated, late vats. The two northern bays, at least $2.6 \mathrm{~m}$ wide and $10 \mathrm{~m}$ long, contained at least ten sunken dolia reinforced externally with hardcore of small stones bonded in white mortar and incorporating a small working platform to the north. The dolia, in which fermentation occurred, were in a typical Cyrenaican fabric of light orange colour, rich in micro-shell. It is possible that other dolia existed further west but excavation is required to prove this.

The western part of Room B was very overgrown in the north-west corner and generally this part of the complex was buried beneath a large quantity of fallen rubble that obscured most of the details. This part of the room must have been wholly or partly vaulted and the vaulting may have carried a second floor. There was no evidence for stairs, but these may have been located in the north-west corner of the complex.

Room $\mathrm{C}$ was located in the west bay of the complex, north of Room A but not directly connected to it. The room measured $4.5 \mathrm{~m}$ by $3.75 \mathrm{~m}$ and was connected to Room B by a doorway

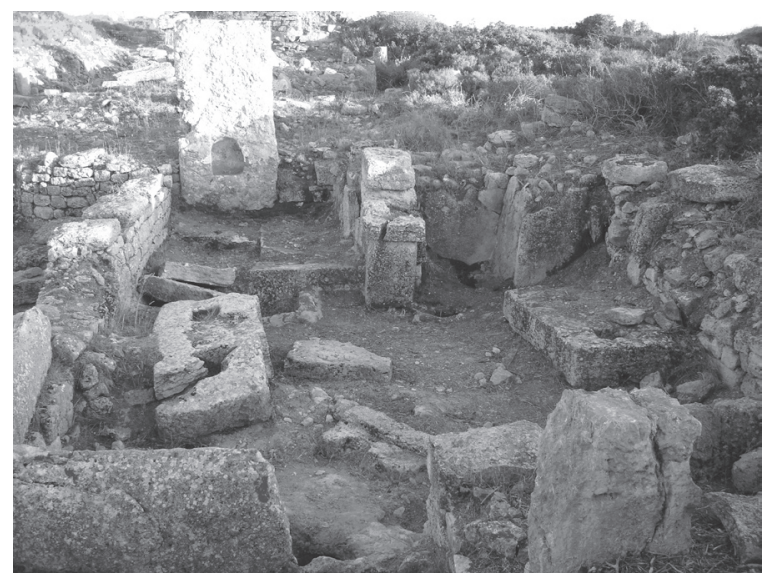

Figure 7. Room A, looking south. 
set centrally in the east wall of the room. Lining the south and west walls of the room and visible above the rubble debris were stone brackets, at least two of which, at the south end of the west wall, were covered by stone slabs. The function of this room is not clear, but it may have served as an office or tool store. A doorway set centrally in the north wall of the room gave onto a narrow room, C1, barely $2 \mathrm{~m}$ wide. The room, possibly a vestibule, had a matching doorway in its north wall with an arched opening giving onto a further room to the north which was obscured by both rubble and vegetation. In the collapsed rubble filling the room was a number of dressed slabs for shelving, suggesting the room to the north may have served a similar purpose to Room C.

\section{Later Occupation}

It is clear that Room B and other parts of the complex witnessed later modification, perhaps after the press room fell into disuse. There are several blocked doors and when Room B was no longer used, the dolia were infilled and a wall built along the axis of the two northern vaults to create a new rectangular room, B1, with a central doorway opening to the west. Three piers of the earlier arrangement were incorporated into the fabric of the later wall, which rested directly over a row of five storage vessels (Fig. 8). A flimsy wall formed the south side of Room B1. Against the south side of the wall was a vat $1.2 \mathrm{~m}$ in diameter and close-by to the south, a sunken dolium $95 \mathrm{~cm}$ in diameter. These last two storage vessels were undoubtedly later than the press room and associated levels and contemporary with the late modifications.

\section{Interpretation}

The evidence from Room A almost certainly indicates the production of wine rather than olive oil. ${ }^{3}$ This interpretation is supported by the absence of crushing mills or basins and of pressing beds with grooves. It is worth mentioning that many basins for olive mills can be seen scattered all over the site, but none have been found in association with this complex. Furthermore, there is no space in Room A to accommodate the kinds of crushing and pressing activities required for oil production. There are no settling tanks of any size for oil production and the lining of tanks 2 and 3 extended higher up the walls

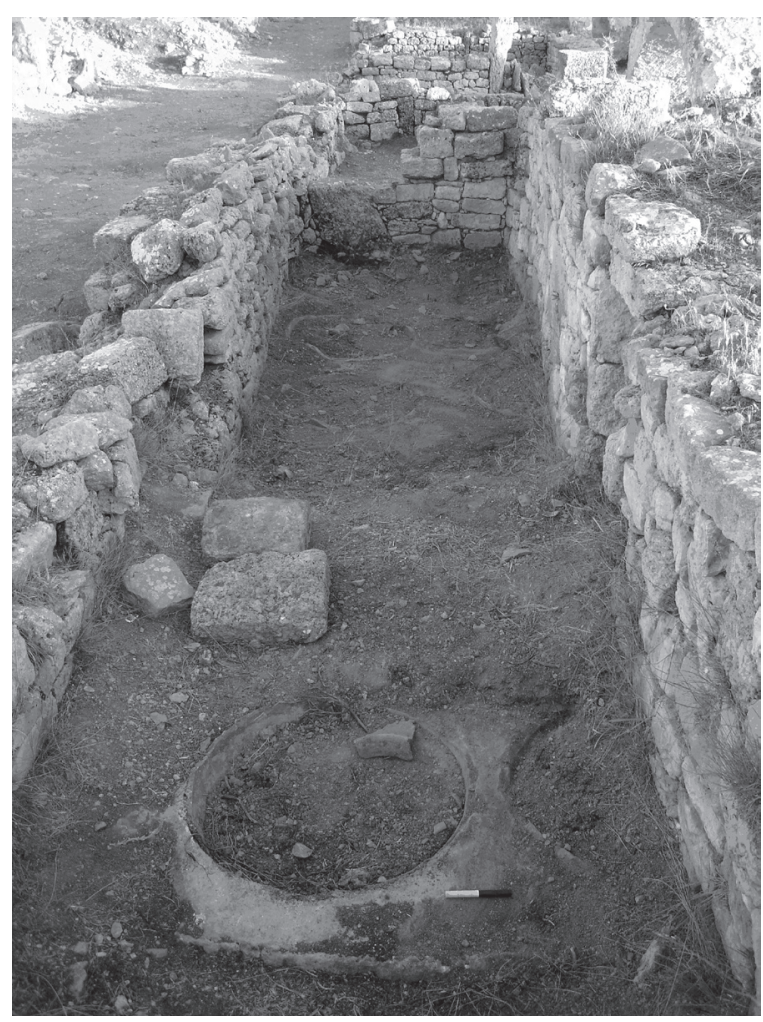

Figure 8. Room B1 with later wall built over the dolia, looking south. Scale: $20 \mathrm{~cm}$ than would have been necessary for oil production. It is clear that the grape treading process was performed in tank 3 with resultant liquid flowing directly into vat 4 , without going through a phase of settling as would have been the case for olive oil. Excavations at Balagrae have revealed clear evidence for this kind of wine manufacture (Buzaian and Bentaher 2006; forthcoming). Having trodden the grapes and extracted juice, more is then produced from the pulp by mechanical pressing in tank 2 , that was also connected with vat 4 . Such techniques appear to have been similar to those adapted in one of the above-ground facilities found in complex B of Siret Gasrin el-Giamel (Brun 2004, 88-89; Catani 1998; Wilson, forthcoming), a few kilometres east of Balagrae. The low stack height (c. $50 \mathrm{~cm}$ ) implied by the difference between the elevations of the niche in the uprights and the press beds would also fit wine production better than olive oil production. In addition, sunken dolia are usually used in the fermentation of grape juice. Environmental sampling in the future of similar structures at Lamluda will greatly assist in this interpretation. 
In the absence of excavation and artefactual study, a definitive interpretation of the complex and above all its date, cannot be put forward. On the basis of observations made following the clearance of vegetation, however, the complex appears to be of Late Roman and perhaps of sixth-century date. This is suggested by the reused stone, bearing three faintly visible carved Maltese crosses, found incorporated in tank 2 of Room A. The date of the later phase of occupation can only be surmised, but the presence of the storage vessels clearly implies continuing production, but on a much reduced level. It is tempting to relate this later activity to continuing occupation after the Arab conquest of the mid-seventh century. Another possible indication of continuity of occupation at Lamluda is an Arabic inscription found in the neighbourhood of the east church, now on display in the museum of Cyrene (Ward-Perkins and Goodchild 2003, 299, n. 6).

\section{Acknowledgments}

I would like to express my heartfelt thanks to Abdalgader al-Mzeini, the Controller of the Department of Antiquities at Shahat for his kind permission to carry out this work. My special thanks are due to Oliva Menozzi and Fathalah Khaleefa for their encouragements. I am most grateful to Paul Bennett and Fuaad Bentaher for much helpful discussion. Sincere thanks are due to both Profs Andrew Wilson and David Mattingly for their valuable comments on the text. Finally, deepest thanks must go to Mohammed al-Twati and Moammer Ghoma for their immeasurable assistance and friendship.

\section{Notes}

1 The results of this survey will be published in a separate paper.

2 A similar counterweight made from a reused frieze block was found in House G at Ptolemais. This block, in Room IA and others elsewhere within the building were uprights for olive presses (J. B. Ward-Perkins, et al., Libyan Studies, 17, p. 121). Later, David Mattingly was convinced that these represented the remains of screw presses (Mattingly 1994, n.44). In fact, the block in House G represented a counterweight stone with two perforations and grooves cut on the underside for mounting the windlass. This technique is consistent with other forms in the region and proves that the press was of conventional type. It is worth mentioning that this counterweight stands vertically in Room IA and it was not laid in its original position (set with its long axis parallel to and just beside the prelum). Since the space available within the room does not allow for engaging in industrial activity, it is, therefore, more probable that the counterweight had been reused in a later phase of activity, not related to oil or wine production.

3 Andrew Wilson has counted some 50 uprights for oil presses at Lamluda (Wilson 2004, 149). During my last survey I recorded 60 uprights and noticed that a significant number of them were probably associated with wine production.

\section{References}

Barker, G.W.W. and Jones, G.D.B. 1984. ULVS VI: Investigations of a Romano-Libyan Farm. Libyan Studies 15: $1-45$.

Brun, J.-P., 2004. Archéologie du vin et de l'huile dans l'Empire romain, Paris.

Buzaian, A. and Bentaher, F. 2006. Excavations at Balagrae (al-Beida) 2001-2003. In Fabbricotti, E. and Menozzi, O. Cirenaica: studi, scavi e scoperte. Parte I: Nuovi dati da città e territorio. British Archaeological Reports International Series 1488: 153-62.

Buzaian, A. and Bentaher, F. (forthcoming). Roman wine production in Cyrenaica: New evidence from Balagrae (al-Beida). XI Convegno di Archeologia Cirenaica, Urbino, 30 giugno-2 luglio 2006.

Catani, E. 1998. Fasi edilizie e tecniche murarie della fattoria paleobizantina di Siret el Giamel nella Chora Cirenea. In Catani, E. and Marengo, S.M. La Cirenaica in età antica, Atti del Convegno internazionale di studi, Macerata, 18-20 Maggio 1995, Pisa - Roma: 113-35.

Mattingly, D.J. 1994. Olive Press in Roman Africa: Technical Evolution or Stagnation?, L'Africa romana, XI: 577-95.

Mattingly, D.J. and Dore, J.N. 1996. Romano-Libyan Settlements; Typology and Chronology. In Barker, G.W.W., Gilbertson D., Jones, G.D.B., and Mattingly, D.J. (eds), Farming the Desert. The Unesco Libyan Valleys Archaeological Survey, Vol. I: Synthesis. UNESCO, Department of Antiquities, Tripoli, Society for Libyan Studies, London.

Menozzi, O. and Fossataro, D. (forthcoming). GIS project in Cyrenaica. From a 'macro-GIS' of the survey to the intra-site analysis of excavation: problems and proposals. Paper for Computer Applications and Quantitative Methods in Archaeology (CAA) conference, 'On the Road to Reconstructing the Past' April 2008. 
Roques, D. 1987. Synésios de Cyrène et la Cyrénä̈que du Bas-Empire. Études d’Antiquités Africaines, Centre National des Recherches Scientifiques, Paris.

Ward-Perkins, J.B. and Goodchild, R.G. (ed. Reynolds, J.) 2003. Christian Monuments of Cyrenaica. London.

Ward-Perkins, J.B., Little, J.H., Mattingly, D.J. and Gibson, S.C. 1986. Town houses at Ptolemais, Cyrenaica: a summary report of survey and excavation work in 1971, 1978-1979. Libyan Studies 17: 109-53.

Wilson, A. 2004. Cyrenaica and the late antique economy. Ancient West and East 3.1: 143-54.

Wilson, A. (forthcoming). Olive oil production in ancient Cyrenaica. Paper for Pula conference, November 2006. 